\title{
Quantitative evaluation of alkalinizing features of natural mineral waters of Transcarpathia
}

\author{
LEMKO Ivan S. ${ }^{1}$, HAYSAK Margarita O. ${ }^{1}$, DYCHKA Lyudmila V. ${ }^{1,2}$
}

${ }^{1}$ Government Institution “The Scientific-practical Medical Centre "Rehabilitation" Health Ministry of Ukraine", ${ }^{2}$ Uzhgorod National University, Uzhhorod, Ukraine

Corresponding author: LEMKO Ivan S., Email: rehab uzh@ukr.net

\begin{abstract}
Introduction. Today latent acidosis resulting from gradual reduction of the buffer reserves of the organism is increasingly the focus of interest because of its role in the development and progression of chronic diseases and comorbidity. One of the promising prophylactic methods of alkalinizing therapy in case of chronic diseases is the correction of the acid-base balance of the body. In preventive medicine, natural mineral waters with predominance of bicarbonate in their anionic composition can be used for alkalinizing therapy. Aim. Investigation of the peculiarities of alkalinizing features of natural mineral waters with different total mineralization and composition. Materials and Methods. In vitro evaluation of natural alkalinity and alkalinizing profile of mineral waters of Transcarpathia were carried out using in vitro methods and calculation models: assessment of $\mathrm{pH}$, buffering and acid-neutralizing capacity (modified after J.S. Fordtran); calculation of potential renal acid load (PRAL) using physiologically based calculation model (T. Remer \& F. Manz). Results. Different types of mineral waters were investigated in the study. Due to the geological origin of their formation, almost all types of Transcarpathian mineral waters contain in their anionic composition bicarbonate. It was found that the level of $\mathrm{pH}$ for the majority of mineral waters lays in a neutral or slightly alkaline range. Their acid-neutralizing capacity varied from 3 to $244 \mathrm{mmol} / 100 \mathrm{ml}$, the calculated PRAL Index values varied between $+1,57$ (for mineral waters with mineralization $0,3 \mathrm{~g} / \mathrm{l}$ ) and $-115,6$ (for mineral waters with mineralization $11,6 \mathrm{~g} / \mathrm{l}$ ) indicating their pronounced alkalinizing features. It was also found that PRAL negatively correlated with $\mathrm{HCO}_{3}{ }^{-}, \mathrm{Na}^{+}, \mathrm{Mg}^{++}, \mathrm{Ca}^{++}, \mathrm{K}^{+}$content $(\mathrm{p}<0.001)$. According to their acid-binding capacity and systemic alkalinizing effect, the studied mineral waters may be classified into two groups. Acid-buffering mineral waters with the index of acid-neutralizing capacity $>40 \mathrm{mmol} / 100 \mathrm{ml}$ and negative PRAL Index; the acid-neutralizing $\mathrm{pH}$ profile and alkalinizing features of these mineral waters are characteristic for those of antacids. Mineral waters with slightly expressed alkalinity with the index of acid-neutralizing capacity $<40 \mathrm{mmol} / 100 \mathrm{ml}$ and negative PRAL Index; their acid-neutralizing influence may be realized due to diluting of gastric juice; they may be used only for the preventive purposes and in cases of slight manifestations of low-grade metabolic acidosis. Conclusions. Thus, mineral waters with different content of bicarbonate and mineralization have pronounced alkalinizing features, which may be evaluated quantitatively using complex of in vitro methods and calculation model.
\end{abstract}

Key words: mineral water, acid-binding and alkalinizing potential, metabolic acidosis,

\section{Introduction}

Today latent acidosis resulting from gradual reduction of the buffer reserves is increasingly the focus of interest because of its role in the development and progression of chronic diseases and comorbid conditions associated with chronic diseases of broncho-pulmonar, cardiovascular, digestive, endocrine systems $(1,2)$.

Over time, ingestion of a high dietary acid load, different medical and toxic influences, overusing of acidosis-formed medications, especially at patients with chronic diseases, can lead to the development and progression of chronic low-grade level of metabolic acidosis. The incidence of this pathological process has been well documented. A chronic acidic load can cause a number of health conditions such as osteoporosis, kidney disease, muscle wasting, rheumatoid disorders, urolithiasis,

bone loss, cardiometabolic diseases, metabolic intoxication with accumulation of such endogenous substances as lactic, pyruvic, conditions. uric acids (1-5). These processes may be a background for the development of polymorbid conditions. Under the of metabolic acidosis, the functioning of hormones, peptides and other regulatory mediators changes, a decrease in the level of insulin and the activity of the hormone. Precise regulations of the acid base homeostasis involves many factors. Even small changes in $\mathrm{pH}$ have crucial effects on cellular function. The major buffer system of the organism in the blood is the $\mathrm{CO}_{2}$-bicarbonate buffer system. It is the most powerful blood buffer for metabolic acids. The increased acid load can lead to a disruption in acid-alkaline homeostasis in various body compartments and eventually result in chronic 
disease through repeated borrowing of the body's alkaline reserves (6-9) and thus, for example, results in calcium-deficit conditions and osteoporosis.

The chronic stage of metabolic acidosis is characterized by extended clinically asymptomatic period and may be revealed only in laboratory studies. Ordinary tests cannot reveal the shift to acidity because humans have an enormous buffer capacity. Mild chronic metabolic acidosis can occur despite normal blood $\mathrm{pH}$ and bicarbonate levels. In cases of metabolic acidosis, humans try to eliminate $\mathrm{H}^{+}$ions in body fluids. The degree of metabolic acidosis is mild as judged by the degree of the blood acid-base balance, but it cannot be considered mild as judged by its negative physiological effects $(4,5)$. Also, it must be noted that latent metabolic acidosis is a potentially reversible process under the influence of alkalinizing therapy which promotes upgrading alkaline reserves of the organism and influences the compensation mechanisms. These measures allow stopping the progression of metabolic intoxication and preventing the development of its somatic stage and comorbid conditions. In preventive medicine, natural mineral waters with predominance of bicarbonate in their anionic composition can be used for the purpose of alkalinizing therapy (10-11).

In this context, it was revealed that consumption of mineral waters rich in bicarbonate was suggested to be a suitable source of alkali-formers (12). P. Burckhardt stated that these waters are the most effective practical measures to increase the dietary alkali load (13). A systemic review of the Medline data concerning 150 commercially available European mineral waters was made and their alkalinizing features were calculated using PRAL index (14). The authors of the study examined the question of which nutritional components are conditioning the acidity or alkalinity of mineral waters and their $\mathrm{Ca}$ content, in order to define the optimal profile for a positive effect on bone. Other group of investigations testified positive changes in calcium balance and bone metabolism after consuming bicarbonate-rich mineral waters resulting in reduced bone resorption, increased bone formation and improved $\mathrm{Ca}$ balance, a decrease in calciuria and of bone resorption markers, increase of calcium level in the hair proving high bioavailability of calcium from the mineral water (15-17). These studies have shown that alkali, bicarbonate-rich mineral waters, especially waters with a strongly negative PRAL value, decrease bone resorption, even when compared with mineral waters with a higher calcium content, and even in the situation of a sufficient calcium intake, and thus, can contribute to the prevention of bone loss.

A single-centered, randomized trial concerning influence of mineral waters with different bicarbonate content on the diet dependent acid load revealed that consumption of at least $1500-2000 \mathrm{ml}$ of bicarbonate-rich mineral water $(>1800 \mathrm{mg} / \mathrm{l})$ with medium or low PRAL can effectively reduce the net acid excretion reducing the dietary acid load under free-living conditions (2).

Large-scale studies concerning curative efficacy of different types of Transcarpathian mineral waters were performed. Because of predominant presence of bicarbonate in composition, first of all their acidbinding and alkalinizing features were studied (18).

So, natural mineral waters, which contain bicarbonate, represent one of the effective methods of detoxification therapy. Their main effect is alkalinizing and is characteristic in fact for all bicarbonate-rich mineral waters with alkaline or neutral $\mathrm{pH}$. At the same time the level of alkalinizing influence and clinical effect depend on the peculiarities of chemical composition of the given mineral water.

\section{Objective}

Investigation of the peculiarities of acid-binding and systemic alkalinizing potential of natural bicarbonate containing mineral waters with different total mineralization and composition.

\section{Materials and methods}

In vitro evaluation of natural alkalinity (alkalinizing features) was conducted for different types of Transcarpathian mineral waters in vitro using two groups of indices:

1. the level of the acid-neutralizing features of mineral waters (buffering capacity and acidneutralizing capacity) after J.S. Fordtran in our modification (19);

2. estimation of systemic alkalinizing features through the calculation of the PRAL Index (potential renal acid load) using the modified method of T. Remer \& F. Manz (20, 21).

Buffering capacity is the indicator for the bufferantacid features of a given mineral water. It is a chemical indicator, which reflects the ability of mineral water to resist changes in its $\mathrm{pH}$ level. It is measured quantitatively by the volume (in $\mathrm{ml}$ ) of $0,1 \mathrm{~N}$ of $\mathrm{HCl}$, which is necessary to change the $\mathrm{pH}$ of $100 \mathrm{ml}$ of mineral water per unit. 
Acid-neutralizing capacity is a physiologicalpharmacological indicator of the expressiveness of acid binding properties of the mineral water. Its value is detected by titration of $100 \mathrm{ml}$ of mineral water with $0.1 \mathrm{~N} \mathrm{HCl}$ to $\mathrm{pH} 3.0-3.5$. The index reflects the duration of the alkalinizing effect of the mineral water.

PRAL - for bicarbonate containing mineral waters, the PRAL index has a negative value and reflects their systemic alkalinizing effects. The more is its absolute value, the more pronounced are the systemic alkalinizing effects of the given mineral water.

The in vitro measurement of the acid-base ratio of diets is the calculation model developed by Remer $\&$ Manz (20). It can also be applied to mineral waters. The PRAL index for each individual mineral water was calculated as described by Wynn et al. (14), using a conversion factor of 0,0146 for $\mathrm{SO}_{4}$ :

$\mathrm{PRAL}=\left[0,0146 \mathrm{SO}_{4}(\mathrm{mg})+0,027 \mathrm{Cl}(\mathrm{mg})+0,037\right.$ $\mathrm{P}(\mathrm{mg})]$

- $[0.021 \mathrm{~K}(\mathrm{mg})+0.026 \mathrm{Mg}(\mathrm{mg})+0.0413 \mathrm{Na}(\mathrm{mg})$ $+0.013 \mathrm{Ca}(\mathrm{mg})]$.

For in vitro evaluation of natural alkalinity (alkalinizing potential) were tested different types of commercially available natural mineral waters of Transcarpathia containing different amounts of bicarbonate.

\section{Results}

Due to the geological origin of their formation, almost all types of Transcarpathian mineral waters contain in their anionic composition bicarbonate. The mean values of their acid-neutralizing properties are presented in the Table 1 and Figure 1.

Table 1. Acid-neutralizing properties of natural bicarbonatecontaining mineral waters of Transcarpathia

\begin{tabular}{|l|l|l|l|l|l|l|}
\hline Mineral water & $\mathbf{M}, \mathbf{g} / \mathbf{l}$ & $\mathbf{p H}$ & $\begin{array}{l}\mathbf{C O}_{2}, \\
\mathbf{m g} / \mathbf{l}\end{array}$ & $\begin{array}{l}\mathbf{H C O}^{-}, \\
\mathbf{m g} / \mathbf{l}\end{array}$ & $\begin{array}{l}\mathbf{B C}, \\
\mathbf{m m o l} / \mathbf{1} \\
\mathbf{0 0} \mathbf{~ m l}\end{array}$ & $\begin{array}{l}\mathbf{A N C}, \\
\mathbf{m m o l} / \\
\mathbf{1 0 0} \mathbf{~ m l}\end{array}$ \\
\hline Pasika & 23,8 & 6,9 & 1771 & 14437 & 206 & 244 \\
\hline $\begin{array}{l}\text { Polyana } \\
\text { Kvasova }\end{array}$ & 10,6 & 6,8 & 1681 & 7076 & 81 & 105 \\
\hline Polyana Kupil & 9,6 & 6,9 & 1729 & 5953 & 68 & 92 \\
\hline Luzhanska-7 & 8,3 & 6,8 & 1829 & 5627 & 64 & 92 \\
\hline Nelipinska & 3,0 & 6,4 & 1199 & 2226 & 27 & 52 \\
\hline Svalyava & 5,8 & 6,4 & 1496 & 4132 & 28 & 69 \\
\hline Ploskivska & 5,0 & 6,4 & 1562 & 3500 & 38 & 62 \\
\hline Shajanska-4 & 4,6 & 6,1 & 1900 & 1830 & 41 & 59 \\
\hline Shajanska-242 & 3,8 & 6,4 & 1700 & 2135 & 33 & 51 \\
\hline Sojmi & 6,7 & 6,4 & 1872 & 3400 & 43 & 62 \\
\hline Drahivska & 6,6 & 6,0 & 1900 & 2300 & 29 & 42 \\
\hline Kelechinska & 1,8 & 6,0 & 1800 & 1450 & 13 & 19 \\
\hline Derenivska & 0,8 & 7,2 & $\mathrm{~N}$ & 415 & 3 & 10 \\
\hline Karpatska & 0,6 & 6,8 & 90 & 226 & 3 & 4 \\
\hline Uzhgorodska-1 & 1,8 & 6,8 & 1010 & 350 & 7 & 9 \\
\hline
\end{tabular}

Notes: $\mathrm{M}$ - total mineralization, $\mathrm{BC}$ - buffering capacity, ANC - acid-neutralizing capacity.

The method of titration by $0,1 \mathrm{~N} \mathrm{HCl}$ is used in US Pharmacopea regulations and regulations of other countries for in vitro evaluation of antacids profile (22). We can see that the highest value of acid binding capacity in the range is 16,55 . At the same time, for the bicarbonate-rich mineral waters this value is significantly higher than for commonly used antacids.

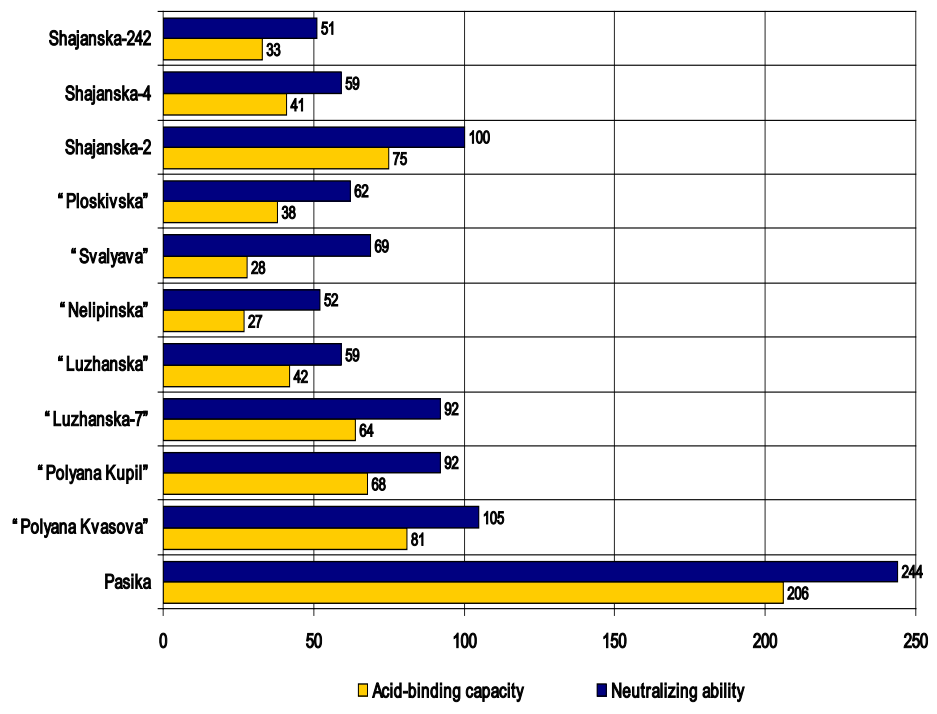

Fig.1. Acid-neutralizing properties of natural bicarbonatecontaining mineral waters of Transcarpathia and acid-binding capacity in $\mathrm{meq} / \mathrm{g}$ for frequently used antacids (US Pharmacopea XXX, method 301)

As it is seen from data presented in the Table 1, the level of $\mathrm{pH}$ for the majority of mineral waters varies in a small range (neutral and slightly alkaline), but their buffering and acid-neutralizing capacity varied from 3 to $244 \mathrm{mmol} / 100 \mathrm{ml}$.

Depending on the desired effect, the technologies of therapeutic internal use of mineral waters also involve artificial reduction of mineralization (dilution) of high- and medium-mineralized waters using low-mineralized drinking water, as well as their heating to different temperatures. In this case, it is very important to maintain the alkalinizing features of the mineral water at an effective level. It was found, that the dilution of mineral waters leads to approximately proportional decrease of their buffering- and acid-neutralizing capacity levels. At the same time, only a slight decrease in the buffering capacity values was observed, while when heating the mineral water to $37-38^{\circ} \mathrm{C}$ and $42^{\circ} \mathrm{C}$ their acidneutralizing capacity levels in fact remained unchanged (Table 2). 
Table 2. Influence of dilution and heating on the acidneutralizing properties of high-mineralized bicarbonate-rich mineral water in vitro

\begin{tabular}{|l|l|l|l|}
\hline \multirow{2}{*}{$\begin{array}{l}\text { Mineral } \\
\text { water, } \\
\text { M 23,8 g/l }\end{array}$} & \multicolumn{3}{|l|}{$\begin{array}{l}\text { Acid-neutralizing properties, mmol/100 ml, } \\
\text { temperature, }{ }^{\mathbf{0}} \mathbf{C}\end{array}$} \\
\cline { 2 - 4 } & $\mathbf{2 0 - 2 2}$ & $\mathbf{3 7 - 3 8}$ & $\mathbf{4 5 - 5 0}$ \\
\cline { 2 - 4 } & Buffering capacity & $176,6 \pm 3,14$ \\
\hline Natural & $206,15 \pm 5,8$ & $178,8 \pm 3,32$ & $72,8 \pm 2,24$ \\
\hline $\begin{array}{l}\text { Dilution } \\
1: 1\end{array}$ & $89,0 \pm 3,14$ & $73,0 \pm 4,05$ & $27,6 \pm 2,26$ \\
\hline $\begin{array}{l}\text { Dilution } \\
1: 2\end{array}$ & $50,0 \pm 3,87$ & $38,6 \pm 2,26$ & $240,4 \pm 1,35$ \\
\hline & Acid-neutralizing capacity \\
\hline Natural & $244,80 \pm 1,35$ & $245,3 \pm 7,63$ & $127,3 \pm 5,16$ \\
\hline $\begin{array}{l}\text { Dilution } \\
1: 1\end{array}$ & $128,6 \pm 2,58$ & $124,0 \pm 1,29$ & $80,6 \pm 3.23$ \\
\hline $\begin{array}{l}\text { Dilution } \\
1: 2\end{array}$ & $91,0 \pm 1,94$ & $87,6 \pm 1,29$ & \\
\hline
\end{tabular}

Notes. $\mathrm{M}$ - total mineralization of the mineral water. Changes in the values of acid-neutralizing properties depending on the dilution are statistically valuable $(\mathrm{P}<0,001)$, under the influence of heating statistically unreliable $((\mathrm{P}>0,05)$.

To estimate systemic alkalinizing features, PRAL was calculated for some bicarbonate-containing mineral waters. These data are presented in the Table 3. It was found that almost all tested mineral waters had PRAL $<0$, its value varied between $+1,57$ (for mineral water with mineralization $0,3 \mathrm{~g} / 1$ and $-115,6$ (for mineral water with mineralization $11,6 \mathrm{~g} / \mathrm{l})$ indicating their pronounced alkalinizing features. It was also found that PRAL negatively correlated with $\mathrm{HCO}_{3}{ }^{-}, \mathrm{Na}^{+}, \mathrm{Mg}^{++}, \mathrm{Ca}^{++}, \mathrm{K}^{+}$content $(\mathrm{P}<0.001)$.

Table 3. Potential renal acid load (PRAL) Index for Transcarpathian mineral waters

\begin{tabular}{|l|l|l|l|l|l|l|}
\hline Mineral waters & $\mathbf{M}, \mathbf{g} / \mathbf{l}$ & $\begin{array}{l}\mathbf{H C O} \mathbf{3} \\
\mathbf{m g} / \mathbf{l}\end{array}$ & $\begin{array}{l}\mathbf{M g}, \\
\mathbf{m g} / \mathbf{l}\end{array}$ & $\begin{array}{l}\mathbf{N a}, \\
\mathbf{m g} / \mathbf{l}\end{array}$ & $\begin{array}{l}\mathbf{C a}, \\
\mathbf{m g} / \mathbf{l}\end{array}$ & PRAL \\
\hline Polyana Kvasova & 11,6 & 7625 & 18,0 & 3138 & 96,4 & $\mathbf{- 1 1 5 , 6}$ \\
\hline Polyana Kupil & 9,6 & 6405 & 33,8 & 2547 & 92,6 & $\mathbf{- 9 5 , 4}$ \\
\hline Shajanska & 4,8 & 3001 & 29,4 & 1235 & 79,3 & $\mathbf{- 4 3 , 5}$ \\
\hline Luzhanska & 5,9 & 4087 & 29,7 & 1428 & 118,6 & $\mathbf{- 5 3 , 6}$ \\
\hline Kelechinska & 1,8 & 1342 & 33,1 & 122,1 & 313,6 & $\mathbf{- 7 , 1}$ \\
\hline Ploskivska & 6,1 & 4270 & 22,5 & 1386 & 77,7 & $\mathbf{- 5 0 , 5}$ \\
\hline Sojmi & 6,6 & 3538 & 67,5 & 1191 & 641,3 & $\mathbf{- 3 0 , 1}$ \\
\hline Drahivska & 6,6 & 2806 & 29,4 & 1890 & 108,6 & $\mathbf{- 3 8 , 2}$ \\
\hline Derenivska & 0,3 & 170 & 11,0 & 11,0 & 25,0 & $+\mathbf{1 , 5 7}$ \\
\hline
\end{tabular}

Note: $\mathrm{M}$ - total mineralization of the mineral water.
According to their acid-neutralizing capacity mineral waters containing bicarbonate may be classified into two groups:

- Acid-buffering mineral waters with the acidneutralizing capacity index value $>40 \mathrm{mmol} / 100 \mathrm{ml}$. Calculated PRAL Index is strongly negative. Their acid-neutralizing $\mathrm{pH}$ profile and alkalinizing potential are characteristic for antacids.

- Mineral waters with slightly expressed alkalinity with the acid-neutralizing capacity index value $<40$ mmol / $100 \mathrm{ml}$. Calculated PRAL Index is negative. Their acid-neutralizing influence is maintained due to the dilution effect; they may be used only for the preventive purposes and in cases of slight manifestations of low-grade metabolic acidosis.

The results obtained in vitro were confirmed in clinical studies of alkalinizing effect of a single dose of mineral waters taken into the stomach during intragastric pH-metry. 272 measurements were carried out using bicarbonate containing mineral waters with different mineralization and composition.

When taken into the stomach, mineral waters has two stages of their effect: a short-term deeper alkalinizing of acidic gastric juice to a $\mathrm{pH}$ level of 6.5-7.0, which lasts up to 5-10 minutes, then, for another 15-40 minutes (depending on the alkalinizing potential), mineral waters maintain the $\mathrm{pH}$ of gastric secret at the level of 3.5-5.0.

Accounting the average duration of alkalinizing effect depending on the level of alkalinizing potential mineral waters were classified into several groups presented in the Table 4 . These data allow in vitro conditions to determine the drinking regime for a particular mineral water depending on its alkalinizing properties.

Table 4. Average duration of alkalinizing effect of mineral waters depending on the level of their alkalinizing potential

\begin{tabular}{|l|l|l|l|}
\hline \multirow{2}{*}{$\mathbf{N}$} & $\begin{array}{l}\text { Acid-neutralizing } \\
\text { capacity, } \\
\text { mmol/100 ml }\end{array}$ & $\begin{array}{l}\text { Duration of } \\
\text { effect, min. }\end{array}$ \\
\cline { 3 - 4 } & Corpus & Antrum \\
\hline 1. & $<20$ & $<10$ & $<15$ \\
\hline 2. & $20-40$ & $10-12$ & $15-20$ \\
\hline 3. & $40-100$ & $12-17$ & $20-32$ \\
\hline 4. & $100-150$ & $17-20$ & $32-37$ \\
\hline 5. & $150-200$ & $20-25$ & $37-40$ \\
\hline
\end{tabular}




\section{Conclusions}

We can assume that mineral waters with different content of bicarbonate and mineralization have pronounced alkalinizing potential which may be evaluated quantitatively using different in vitro methods and calculation models. Experimental in vitro and in vivo investigations revealed that mineral water rich in bicarbonate is in fact a functional buffer with certain alkalinizing features which depends on the value of their buffering. acidneutralizing properties and PRAL Index. These indicators form the objective basis for quantitative evaluation of mineral waters alkalinizing potential and predicting peculiarities of their clinical use.

\section{Acknowledgements}

The work was carried out within the scientific project of Government Institution "The Scientificpractical Medical Centre "Rehabilitation" Health Ministry of Ukraine". The research was funded by the Ministry of Health of Ukraine at the expense of the State Budget.

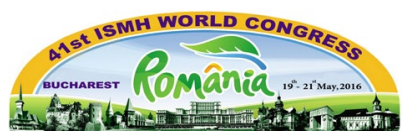

The initial material within the framework of this paper was presented in the 41st ISMH World Congress in conjoint with the Congress of The Romanian Society for Physical and Rehabilitation Medicine and Balneoclimatology (RSPRMB), in Bucharest, Romania, 19 ${ }^{\text {th }}-21^{\text {st }}$ May, 2016 (23).

\section{References}

1. Vormann J, Goedecke T. Acid-base homeostasis: latent acidosis as a cause of chronic diseases. Schweizerische Zeitschrift fur GanzheitsMedizin. 2006; 18(5): 255-266;

2. Wasserfurth P, Schneider I, Ströhle A, Nebl J, Bitterlich N, Hahn A. Effects of mineral waters on acid-base status in healthy adults: results of a randomized trial. Food \& Nutrition Research. 2019; 63: 10.29219/fnr.v63.3515;

3. Lysenko OV. Acid-base state of the body as a diagnostic, prognostic, nosotropic marker of forming of cellular reserve in case of pathological conditions. Collection of scientific works of staff member of P.L.Shupyk NMAPE. 2006; 25: 623629 ;

4. Minich DM, Bland JS. Acid-alkaline balance: role in chronic disease and detoxification. Alternative therapies. Jul/Aug 2007; 13 (4): 6265 ;

5. Sebastian A, Frassetto LA, Sellmeyer DE, Merriam RL, Morris RC Jr Estimation of the net acid load of the diet of ancestral preagricultural Homo sapiens and their hominid ancestors. American Journal of Clinical Nutrition. 2002; 76: 1308-1316;

6. Melamed P, Melamed F. Chronic metabolic acidosis destroys Pancreas // JOP. Journal of the Pancreas. 2014 Nov 28; 15(6): 552-560. https://doi.org/10.6092/1590-8577/2854;

7. Osuna-Padilla IA, Leal-Escobar G, Garza-Garcia CA, Rodriquez-Castellanos FE. Dietary acid load: mechanisms and evidence of its health repercussions. Nefrologia. 2019; 39 (4): 343-354. https://doi.org/10.1016/j.nefro.2018.10.005;

8. Rosner M.H. Metabolic Acidosis in Patients with Gastrointestinal Disorders: Metabolic and Clinical Consequences. Practical gastroenterology. April 2009: 42-52;

9. Fenton TR, Huang T. Systematic review of the association between dietary acid load, alkaline water and cancer. BMJ Open. 2016; 6: http://dx.doi.org/10.1136/bmjopen-2015-010438;

10. Pizzorno J. Acidosis: An Old Idea Validated by New Research. Integrative Medicine. 2015; 14 (1): $8-12$; 
11. Adeva-Andany MM, Fernández-Fernández $C$, Mouriño-Bayolo D, Castro-Quintela E, Domínguez-Montero A. Sodium Bicarbonate Therapy in Patients with Metabolic Acidosis. The Scientific World Journal. 2014. doi: 10.1155/2014/627673. Epub 2014 Oct 21;

12. Rylander R. Drinking water constituents and disease. Journal of Nutrition. 2008; 138: 423S425S. doi: $10.1093 / \mathrm{jn} / 138.2 .423 \mathrm{~S}$;

13. Burckhardt P. The effect of the alkali load of mineral water on bone metabolism: interventional studies. Journal of Nutrition. 2008; 138: 435S437S. doi: 10.1093/jn/138.2.435S;

14. Wynn E, Raetz E, Burckhardt P. The composition of mineral waters sourced from Europe and North America in respect to bone health: composition of mineral water optimal for bone. British Journal of Nutrition. 2009; 101: 1195 . doi: 10.1017/S0007114508061515;

15. Heil DP. Acid-base balance and hydration status following consumption of mineral-based alkaline bottled water. Journal of the International society of Sports Nutrition. 2010; 13: 7-29;

16. Greupner T, Schneider I, Hahn A. Calcium bioavailability from mineral waters with different mineralization in comparison to milk and a supplement. Journal of the American College of Nutrition. $\quad 2017 ; \quad 36 \quad$ (5): 386-390. https://doi.org/10.1080/07315724.2017.1299651;

17. Lemko IS, Shubert ST, Haysak MO, Malynovska VG, Dychka LV. Possibilities for calcium and bicarbonate-rich mineral waters in the prevention of calcium-deficit conditions. Balneo Research Journal. 2013; 4 (3): 100-106;

18. Мінеральні води Закарпаття. Питне лікувальне використання, за ред. М.В.Лободи, Л.П.Киртич，Ужгород: «ІВА», 1987, 174 р. (Mineral waters of Transcarpathia: curative drinking use. Ed. Loboda MV, Kirtich LP. Uzhgorod:"IVA", 1987:174 p.);

19. Fordtran JS, Morawsky SD, Richardson CT. In vivo and in vitro evaluation of liquid antacids. New English Journal of Medicine. 1973; 288: 923-928;

20. Remer T, Manz F. Potential renal acid load of foods and its influence on urine $\mathrm{pH}$. Journal of the American Dietetic Association. 1995; 95: 791-797. doi: 10.1016/S0002-8223(95)00219-7;
21. Remer T, Dimitriou T, Manz F. Dietary potential renal acid load and renal net acid excretion in healthy, free-living children and adolescents. American Journal of Clinical Nutrition. 2003; 77: 1255-1260. doi: 10.1093/ajen/77.5.1255;

22. Jacob S, Shirwaikar A., Anoop S, Khaled R, Imtiaz M, Nair A. Acid neutralization capacity and cost-effectiveness of antacids sold in various retail pharmacies in the United Arab Emirates. Hamdan Medical Journal. 2016. http://dx.doi.org/10.7707/hmj.452;

23. Haysak MO, Dychka LV, Holubka OP, Shubert ST. Quantitative evaluation of alkalizing features of natural mineral waters. Balneoresearch Journal. 2016; 7 (2): 101. 